\title{
Empirical Analysis by Examining Critical Success Factors for Project Success during Software Development: Case of Indian Software Development Companies
}

\author{
Gurleen Kakkar \\ Research Scholar, Aligarh Muslim University, Uttar Pradesh, India.
}

CITATION: Kakkar, Gurleen (2019), "Empirical Analysis by Examining Critical Success Factors for Project Success during Software Development: Case of Indian Software Development Companies", MERC Global's International Journal of Management, Vol. 7, Issue 4, pp. 290-300.

ARTICLE HISTORY: Submitted: May 18, 2019, Revision received: July 03, 2019, Accepted: July 13,2019

ARTICLE TYPE: Research article

\begin{abstract}
This paper aims to empirically examine the key critical success factors for project success during software development with reference to Indian software development companies. To achieve this, the study made a quantitative analysis through a questionnaire. A questionnaire was given to key personnel in selected Indian software companies. The findings concluded that Project factors impact the success of a project in the software industry with respect to the costing model, however, it does not show any difference. The study found that senior management support, Requirement Management, Risk management, Schedule Control, Budget Control, Project team competence, Organization culture and agility and Communication are the chief factors involved in the project success of Indian software companies. The study finding shows that there is an impact of senior management commitment on the success of the project. With respect to communication, the study finding shows that there is an impact of communication on the success of the project. This study finding presents that there was found to be a relationship between the project success factor and Effort and Cost Variances.
\end{abstract}

KEYWORDS: Success factors, Software project management, Indian software companies, Project planning.

\section{REFERENCES}

1. Alqahtani, F.; Chinyio, E.; Mushatat, S. and Oloke, D. (2015), "The Links between the Values of AbuDhabi Police and the Competenceis of Their Project Managers", Journal of Engineering and Architecture, Vol. 3, Issue 2, pp. 157-169.

2. Anuar, N. I. and Ng, P. K. (2011), The role of time, cost and quality in project management, in 2011 IEEE MTT-S International Microwave Workshop Series on Innovative Wireless Power Transmission: Technologies, Systems, and Applications, pp. 630-634, IEEE.

3. Bhoola, V. (2015), "Impact of Project Success Factors in Managing Software Projects in India: An Empirical Analysis", Business Perspectives and Research, Vol. 3, Issue 2, pp. 109-125.

4. Biezenaar, H. and Jorritsma, J. (2016), The influence of project size on project performance: Through social network characteristics in the Open Source Software community, Utrecht University.

5. Cleland, D. L. and Gareis, R. (2010), Global Project Management Handbook: Planning, Organizing and Controlling International Projects, McGraw Hill, London, United Kingdom.

6. Crisan-Mitra, C. and Borza, A. (2014), "Strategic entrepreneurship", Managerial Challenges of the Contemporary Society, Vol. 7, Issue 1, pp. 170-174.

7. Davis, K. (2014), "Different stakeholder groups and their perceptions of project success", International Journal of Project Management, Vol. 32, Issue 2, pp. 189-201.

8. Dvir, D.; Lipovetsky, S.; Shenhar, A. and Tishler, A. (1998), "In search of project classification: a nonuniversal approach to project success factors", Research Policy, Vol. 27, Issue 9, pp. 915-935. 
9. Fornell, C. and Larcker, D. F. (1981), "Evaluating Structural Equation Models with Unobservable Variables and Measurement Error", Journal of Marketing Research, Vol. 18, Issue 1, pp. 39.

10. Gangwani, D. and Mukherjee, S. (2015), "Analyzing the Impact of Different Factors on Software Cost Estimation in Today's Scenario", Journal of Software Engineering and Applications, Vol. 08, Issue 05, pp. 245-251.

11. Garson, G. D. (2016), Partial Least Squares: Regression and Structural Equation Models, Statistical Associates Publishers, Asheboro, North Carolina, United States.

12. Hair, J. F.; Ringle, C. M. and Sarstedt, M. (2011), "PLS-SEM: Indeed a Silver Bullet", Journal of Marketing Theory and Practice, Vol. 19, Issue 2, pp. 139-152.

13. Hair, J. F.; Ringle, C. M. and Sarstedt, M. (2014), "Corrigendum to "Editorial Partial Least Squares Structural Equation Modeling: Rigorous Applications, Better Results and Higher Acceptance", Long Range Planning, Vol. 47, Issue 6, pp. 392.

14. Hair, J.; Black, W.; Babin, B.; Anderson, R. and Tatham, R. (2006), Multivariate Data Analysis, Pearson Prentice Hall, Upper Saddle River, New Jersey, United States.

15. Jørgensen, C. B. (2015), Human resource allocation practices in multi-project organizations A case study of human resource allocation practices and the contextual conditions that shape them, University of Agder.

16. Lohmöller, J. B. (1989), Latent variable path modeling with partial least squares. Berlin, Springer, Germany.

17. Marczyk, G. R.; DeMatteo, D. and Festinger, D. (2005), Essentials of Research Design and Methodology, Wiley, Hoboken, New Jersey, United States.

18. Martin, N. L.; Pearson, J. M. and Furumo, K. A. (2005), IS Project Management: Size, Complexity, Practices and the Project Management Office, in Proceedings of the $38^{\text {th }}$ Annual Hawaii International Conference on System Sciences, pp. 234b-234b, IEEE.

19. Meskendahl, S. (2010), "The influence of business strategy on project portfolio management and its success - A conceptual framework”, International Journal of Project Management, Vol. 28, Issue 8, pp. 807-817.

20. Mir, F. A. and Pinnington, A. H. (2014), "Exploring the value of project management: Linking Project Management Performance and Project Success", International Journal of Project Management, Vol. 32, Issue 2, pp. 202-217.

21. Mohtashami, M.; Marlowe, T.; Kirova, V. and Deek, F. P. (2006), "Risk Management for Collaborative Software Development”, Information Systems Management, Vol. 23, Issue 4, pp. 20-30.

22. Müller, R. and Turner, R. (2007), "The Influence of Project Managers on Project Success Criteria and Project Success by Type of Project”, European Management Journal, Vol. 25, Issue 4, pp. 298-309.

23. Munns, A. and Bjeirmi, B. (1996), "The role of project management in achieving project success", International Journal of Project Management, Vol. 14, Issue 2, pp. 81-87.

24. Nasir, M. H. N. and Shamsul, S. (2011), "Critical success factors for software projects: A comparative study”, Scientific Research and Essays, Vol. 6, Issue 10, pp. 2174-2186.

25. Nwakanma, C. I.; Asiegbu, B. C.; Ogbonna, C. A. and Njoku, P. P. C. (2013), "Factors affecting successful implementation of information technology projects: Experts", European Scientific Journal, Vol. 99, Issue 27, pp. 1857-7881.

26. Pinto, J. K. and Slevin, D. P. (1987), "Critical factors in successful project implementation", IEEE Transactions on Engineering Management, Vol. 34, Issue 1, pp. 22-27.

27. Project Management Institute (2013), A Guide to the Project Management Body of Knowledge, Project Management Institute, Newtown Square, Pennsylvania, United States.

28. Ramayah, T.; Cheah, J.; Chuah, F.; Ting, H. and Memon, M. A. (2016), Partial Least Squares Structural Equation Modeling (PLS-SEM) using SmartPLS 3.0: An Updated and Practical Guide to Statistical Analysis, Pearson Malaysia.

29. Salanţă, I. and Popa, M. (2014), An Empirical Investigation Into The Outsourcing Logistics Contract, in $8^{\text {th }}$ International Management Conference (pp. 350-357). Bucharest, Romania: Babes-Bolyai University.

30. Savolainen, P.; Ahonen, J. J. and Richardson, I. (2012), "Software development project success and failure from the supplier's perspective: A systematic literature review", International Journal of Project Management, Vol. 30, Issue 4, pp. 458-469.

31. Shenhar, A. J.; Dvir, D.; Levy, O. and Maltz, A. C. (2001), "Project Success: A Multidimensional Strategic Concept", Long Range Planning, Vol. 34, Issue 6, pp. 699-725.

32. Sudhakar, G. P. (2012), "A model of critical success factors for software projects", Journal of Enterprise Information Management, Vol. 25, Issue 6, pp. 537-558.

33. Tuman, J. (1986), Success modeling: A technique for building a winning project team, in PMI Annual Seminar and Symposium, pp. 94-108, Montreal, Canada: PMI.

34. Turner, R. and Müller, R. (2005), "The Project Manager's Leadership Style as a Success Factor on Projects: A Literature Review”, Project Management Journal, Vol. 36, Issue 2, pp. 49-61.

35. Westerveld, E. (2003), "The Project Excellence Model $\AA$ : linking success criteria and critical success factors", International Journal of Project Management, Vol. 21, Issue 6, pp. 411-418. 
36. Wold, H. O. (1982), Soft Modelling: The Basic Design and Some Extensions, in K. Joreskog \& H. O. Wold (Eds.), Systems under Indirect Observations: Part II (pp. 1-54), North-Holland: Amsterdam, Netherlands.

37. Wong, K. K. K. (2013), "Partial Least Squares Structural Equation Modelling (PLS-SEM) Techniques Using SmartPLS", Marketing Bulletin, Vol. 24, Issue 1, pp. 1-32.

38. Yu, A. G.; Flett, P. D. and Bowers, J. A. (2005), "Developing a value-centred proposal for assessing project success", International Journal of Project Management, Vol. 23, Issue 6, pp. 428-436. 